\title{
A Perspective of the Diurnal Aspect of Thermal Comfort in Nigeria
}

\author{
Oyenike Mary Eludoyin \\ Department of Geography and Planning Sciences, Adekunle Ajasin University, Akungba-Akoko, \\ Nigeria \\ Email: baynick2003@yahoo.com
}

Received 23 August 2014; revised 10 September 2014; accepted 2 October 2014

Copyright (C) 2014 by author and Scientific Research Publishing Inc.

This work is licensed under the Creative Commons Attribution International License (CC BY). http://creativecommons.org/licenses/by/4.0/

(c) (i) Open Access

\section{Abstract}

This study examines the day-time variations in the physiologic comfort of Nigeria using the effective temperature, temperature-humidity and relative strain indices (ETI, THI and RSI, respectively) for 59 years (1951-2009) at 20 well-distributed $\left(2\right.$ by $\left.2^{\circ}\right)$ meteorological stations across Nigeria. It also examines the responses from $\mathbf{3 6 0 0}$ sample population from tertiary institutions across Nigeria. Results indicated thermal stress in Nigeria, and showed that both heat and cold stress varied temporally and spatially (1200 - 1500 Local Standard Time, LST as the most thermally uncomfortable period of the day, while before 0900 and around 2100 LST were more comfortable). The study showed that judgment on climate issues were often beclouded by religious or ignorant sentiments. Efficient coping strategies for thermal stress are generally lacking, being limited by poor education, financial capacity and inadequate government commitment to cater for the health effects of extreme climate conditions. The study concluded that Nigeria, which exemplifies many developing countries, is not yet prepared for the effect of future climate change. The study recommends climate education, improves health schemes for climate-related morbidity and improves greening of the urban environment.

\section{Keywords}

Day-Time Thermal Comfort, Coping Strategies, Effect of Extreme Weather, Climate Education

\section{Introduction}

Human concerns for thermal comfort are generally indisputable, especially with the recent increase in crave for habitat modification and environmental sustainability [1]-[9]. Thermal comfort (sometimes referred to as physiologic comfort) can be described as the human state of physical, mental and social well-being [6] [10]-[12]. The 
human state of well-being is often associated with the interactions between prevailing weather, skin temperature and many other factors (including skin covers, such as wears, previous weather experience, and adaptation factors, such as culture and perceptions) [12]-[14]. It has been argued that people of different cultures consider themselves comfortable across a wide range of temperatures [15] [16]. Busch [13] indicated that some office workers in Thailand felt comfortable at higher indoor temperatures (about $31^{\circ} \mathrm{C}$ ) than those working in more temperate regions.

Information on thermal comfort is required for early warning against climate-related sickness, thermal stress and for planning for holidays, migration, tourism and building [14] [15] [17]-[20]. Thermal comfort is highly related to the occurrence of climate extremes, such as heat waves. Investigations on climate extremes have been carried out especially in Europe: see, for instance, Fritch et al. [21], Piccarreta et al. [22]. Studies on the variations in the thermal comfort in parts of Americas and Europe have shown that thermal stress has increased over the years, and have caused increased cases of heat stress, heat stroke or heat waves, which have been linked with increased mortality and forced migration [23]-[29]. Most of these studies also show the need for social and technical adjustments that might be required to cope with climate extremes, and suggest that changes at the institutional and infrastructural level will be required [14] [17] [19] [20]. In Africa, and other developing continents, where rapid population and urbanisation increase has not been matched with a commensurate change in social, economic and technological development [30]-[32], few studies exist.

Recent studies on the thermal comfort in Nigeria showed that the Nigerian thermal climate may not be well explained by a single thermal index, and therefore suggested the need for a multi-indices approach [33]-[39]. Other studies have also explored the seasonal and annual variations either at city, regional or country scale [33] [34] but information about the hourly variations is scarce. Ayoade [33] used effective temperature index (ETI) and temperature to describe day-time hourly distributions of thermal comfort for Nigeria from 16 stations. While this study established the relevance of ETI to the Nigerian climate, urbanisation and population have significantly increased from the time of its publication (annual urban population growth is estimated at 3.8\%, and annual population growth at $2.5 \%$ ) [40]. The objectives of the present study are therefore to examine the day-time thermal comfort in Nigeria, and assess the preference of Nigerians for thermal comfort condition and their responses to extreme weather conditions. The main hypotheses are that Nigeria is thermally comfortable throughout the year and that the coping strategy is sufficient in case of future thermal stress. Day-time records are chosen because except in the last 5 years that the Nigerian Meteorological Agency (NIMET) began to automate the weather measuring equipment, the night-time data are very scarce, hence night-time variation is not covered in this study.

\section{Study Area}

Nigeria $\left(4^{\circ} \mathrm{N}-14^{\circ} \mathrm{N}\right.$ and $\left.3^{\circ} \mathrm{E}-15^{\circ} \mathrm{E}\right)$ is in the southeastern edge of the West African region and covers about $14 \%$ of West Africa. Nigeria is characterized by dry and rainy seasons. While the dry season is accompanied by the Tropical Continental (cT) airmass influenced dust-laden (Harmattan) wind from the Sahara desert, the rainy season is heavily influenced by the Tropical Maritime (mT) from the Atlantic Ocean (Figure 1).

Areas surrounded by high elevation (especially in the north-central region) can be influenced by the relief rainfall. Studies have classified the Nigerian climate into (a) tropical rainforest climate, (b) tropical savanna climate and (c) highland climate or montane climate [36]. The tropical rainforest climate, designated by the Köppen climate classification as “Af”, characterises the southern region. The Tropical rainforest is sub-grouped into the tropical wet and tropical wet and dry climates, and it is influenced by the equatorial climate (characterised by small temperature range and convectional storms). The Tropical savanna climate comprises the guinea, sudan and sahelsavanna, and characterizes most of the central and northern regions. The Guinea belt occupies the limits of tropical rainforest climate, and extends to the central part while the northern fringe is occupied by the tropical (Sudan) savanna climate. The north-eastern fringes exhibit the Sahelian climate. The tropical savanna climate exhibits a well-marked single peak rainy season and a dry season. Mean temperature in this region exceeds $18^{\circ} \mathrm{C}$ throughout the year, and the dry season, which usually occurs from December to March, is hot and dry with the Harmattan wind, prevailing throughout this period. "Highland climate" [37] or montane climate is experienced on highlands regions in Nigeria. Highlands with montane climate in Nigeria exceed $1520 \mathrm{~m}$ above sea level. Because of their location in the tropics, this elevation provides the settlements on the mountains and the plateau regions standing above this height, a cool montane climate. 


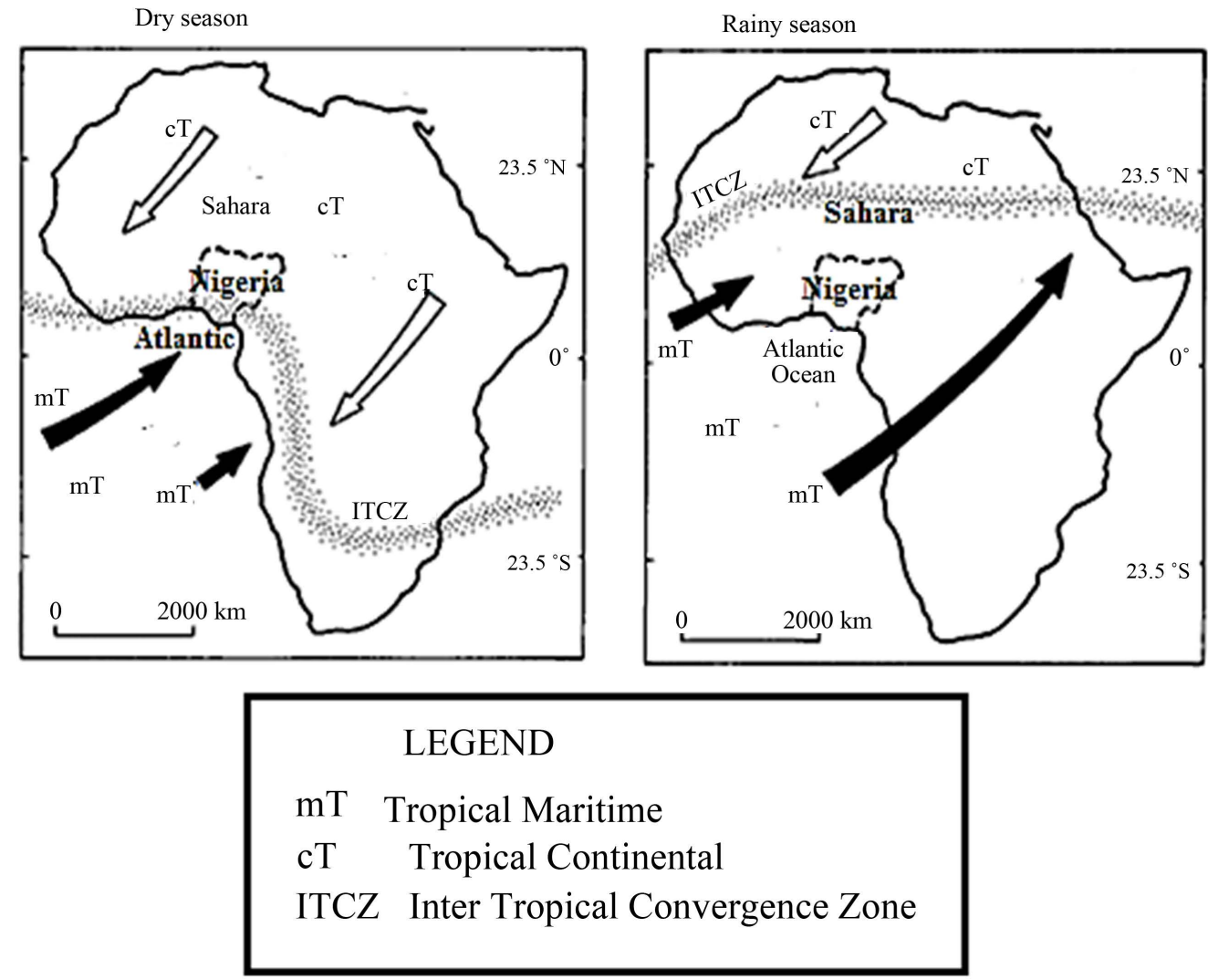

Figure 1. Nigeria in Africa, and the seasonal direction of the air masses and the Inter Tropical Convergence Zone that determine the season in the region.

\section{Materials and Methods}

This study used day-time (0600-2100 Local Standard Time) relative humidity and temperature data for 20 meteorological stations to compute the selected thermal comfort indices. The thermal comfort indices have been used in previous studies, and have been found to be suitable to the Nigerian (and tropical) climate [33] [34] [38] [39]. The 20 stations were selected to represent the different sub-climate types (tropical wet (TW), tropical wet and dry (TWD), guinea savanna (GS), sudan savanna, sahel savanna and montane) (Figure 2(a)). Selected thermal indices are ETI, temperature-humidity index (THI) and relative humidity index (RSI), and they have been well explained in [38]. The values of the indices were determined from the available temperature and relative humidity data with Equations (1)-(3).

$$
\begin{aligned}
\mathrm{THI} & =0.8 T+\frac{H T}{500}, \\
\mathrm{ETI} & =T-0.4(T-10)\left(1-\frac{H}{100}\right), \\
\mathrm{RSI} & =\frac{[10.7+0.74(T-35)]}{44-0.0075 H V}
\end{aligned}
$$

where

$T$ is the mean temperature of the air $\left({ }^{\circ} \mathrm{C}\right), H$ is relative humidity [\%), $V$ is the saturation vapour pressure (in hPA), and is estimated as $V=6.11 \times 10^{\frac{7.5 T}{237.7+T}}$.

An area is classified as thermally comfortable if its atmospheric condition is characterised by ETI values of $18.9^{\circ} \mathrm{C}-25.6^{\circ} \mathrm{C}$ or $\mathrm{THI}$ values of $15^{\circ} \mathrm{C}-24^{\circ} \mathrm{C}$ or RSI values of $0.1-0.2$ (ratio, no unit). Cold stress occurs at 


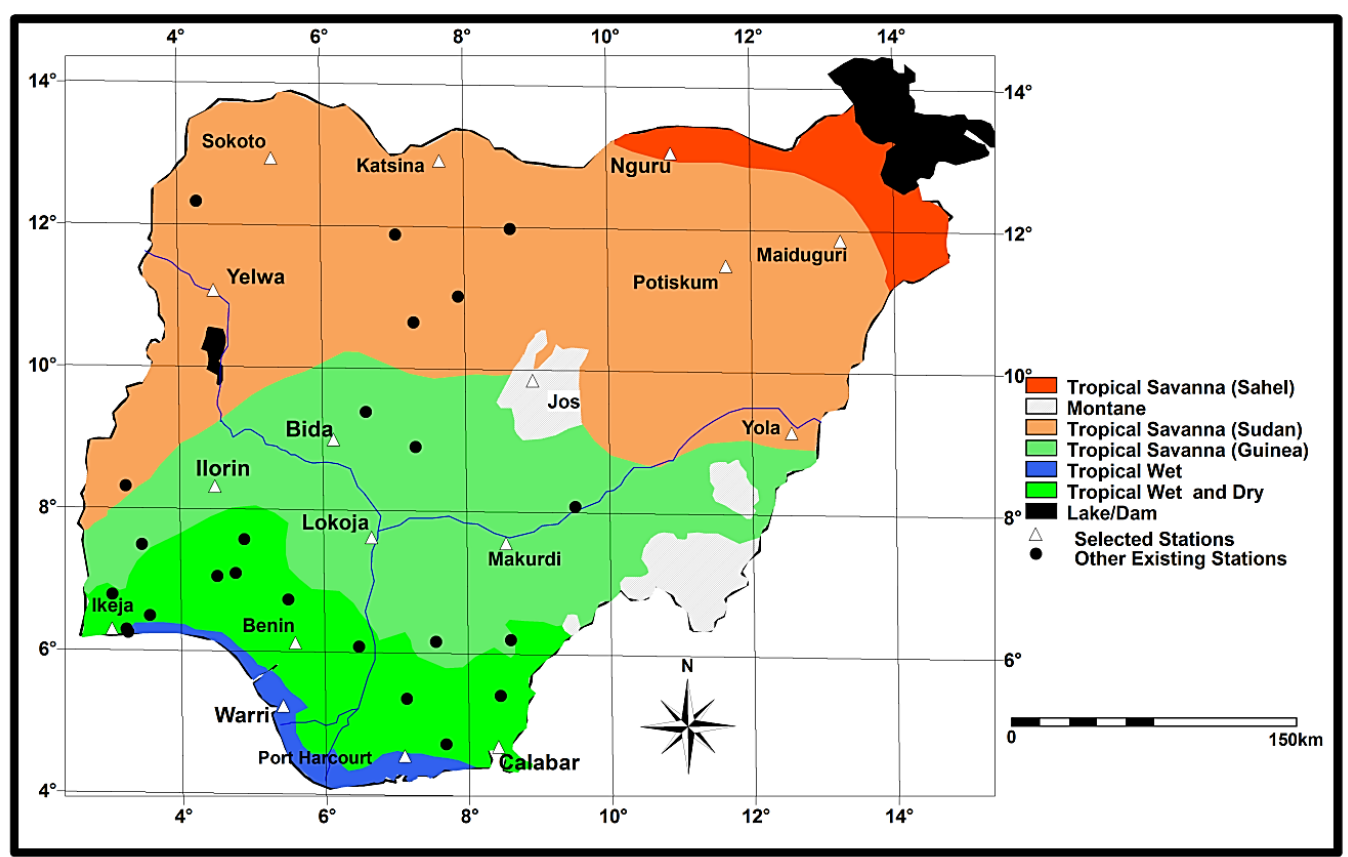

(a)

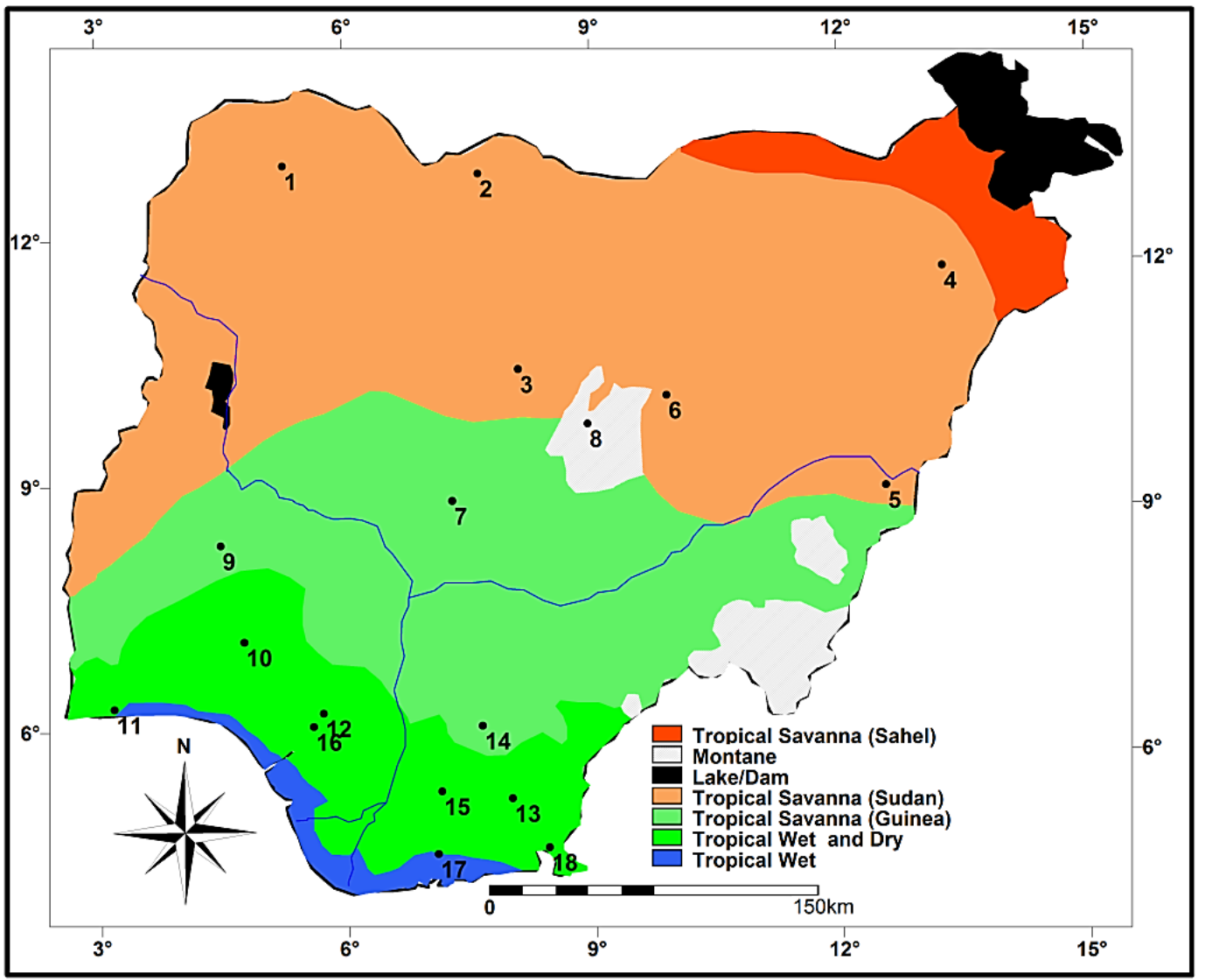

(b)

Figure 2. Locations represented by the datasets used in this study. (a) shows the locations of meteorological data and (b) shows where the tertiary from which responses on coping strategies were obtained. 
values below the minimum while the maximum threshold marks the beginning of a heat stress condition [33] [35]. Day-time thermal comfort was assessed by comparing the day-time hourly (0600-2100 LST) ETI, THI and RSI values for selected meteorological stations. The coolest and warmest years (based on the global temperature model [41] within the study period) were 1971 and 2001, respectively. Day-time thermal comfort for 1971 and 2001 was therefore compared to provide experience for typical cool and warm year thermal comfort for Nigeria. Values for the investigated meteorological stations and periods were interpolated using the moving averages technique to plot the descriptive maps for Nigeria, and the monthly day-time thermal comfort for selected stations with standard geographic information (ILWIS, version 3.4, and a third party, SURFER) software. The sequential steps for the creation of the descriptive maps has been published elsewhere [38] [39].

The preference and responses of Nigerians on thermal comfort was assessed by administering a set of questionnaire to about 200 randomly selected workers from each of purposively selected 18 tertiary (University, Polytechnic, or College of Education) locations in Nigeria (Figure 2(b)). Crocombe and Malama [42] had argued that the responses from a tertiary institution could sometimes be stronger than that of a community, probably because those in schools are likely to be more conscious and inquisitive than others within the entire community. To determine the sampled population the Slovin's formula (Equation (4)) was applied.

$$
\begin{aligned}
\text { Sample population } & =\frac{N}{1+N e^{2}} \\
N=\text { total targeted population, } e & =\text { confidence level }(0.05 \text { for } 95 \%) .
\end{aligned}
$$

A sample size of 200 was finally accepted because less than the targeted sample sizes for most institutions were returned. Almost $60 \%$ of the respondents worked indoor while $40 \%$ worked outdoor. Most of the respondents were adults between the ages of 18 and 60 years, who worked either on full or part time basis at the sample locations. The 18 - 60 years age group makes up the most productive set of the population. More than $70 \%$ of the respondents had lived in the sample location for at least 5 years and this gives the group an advantage of fair understanding of the climate of the sample location. More than $99 \%$ of the respondents had attained at least primary education status (and 67.5\% have had tertiary or post-secondary education), suggesting that they would easily understand the content of the questionnaire and its purpose. At least, $40 \%$ of the workers claimed to make a minimum of five hundred thousand (500,000 Naira) per annum; an equivalent of about US\$9 per day as at the time of the research.

\section{Results and Discussion}

\subsection{Characterisation of the Nigerian Thermal Climate Conditions}

The 59-year (1951-2009) average minimum, maximum and mean temperature in Nigeria (based on the selected 20 stations) is $21.4^{\circ} \mathrm{C}, 32.8^{\circ} \mathrm{C}$ and $27^{\circ} \mathrm{C}$, respectively. Minimum temperatures were generally below the overall mean in the tropical savanna (except at Sokoto and Yola) and montane regions while mean maximum temperature in all stations within the savanna was higher than its overall mean, except at Bauchi and Ilorin. The montane, Tropical Wet and Dry and Tropical Wet climate regions, however, had lower (than the overall average) mean maximum temperature. The mean relative humidity varied between $36.5 \%$ and $85.1 \%$, with $62 \%$ as the mean. Variations in both temperature and relative humidity increased from south towards the north, except for few stations in the guinea and sudansavanna which exhibited higher variability than the sahel. Lowest mean annual ET occurred at the montane region (Jos, $19.4^{\circ} \mathrm{C}$ ) while the highest values occurred at Warri in the tropical wet climate $\left(26.1^{\circ} \mathrm{C}\right)$. Annual ET values at most of the stations within the Sudano-Sahelian (Bauchi, Katsina, Maiduguri, Nguru and Potiskum) and montane (Jos) climate regions are lower than the overall average $\left(24.3^{\circ} \mathrm{C}\right)$. Stations within the guinea savanna, and tropical rainforest on the other hand, exhibited higher ET than the overall average. Highest mean THI $\left(26.3^{\circ} \mathrm{C}\right)$ occurred in Lokoja (Guinea savanna) while the montane station exhibited the lowest $\left(19.6^{\circ} \mathrm{C}\right)$ mean THI. Highest RSI ratio (0.2) occurred at Warri in the Tropical wet climate while the montane region exhibited the smallest ratio (0.01) (Table 1$)$.

The different variability in the investigated parameters suggests that thermal comfort vary substantially across Nigeria, and the differences in the thermal indices also indicate that predicting the Nigerian climate based on a single index approach needs further study. Studies [3] [43] argued that the most of the popular climate models for Nigeria and the sub-Sahara (e.g. Koppen and Thorntwaite's climate [44], are determined on precipitation 
Table 1. Descriptive statistics of temperature, relative humidity and thermal climate at selected meteorological stations in Nigeria (M represents mean, and SD is the standard deviation).

\begin{tabular}{|c|c|c|c|c|c|c|c|c|c|c|c|c|c|c|c|}
\hline \multirow{3}{*}{ Climate Region } & \multirow{3}{*}{$\begin{array}{c}\text { Meteorological } \\
\text { Station }\end{array}$} & \multicolumn{6}{|c|}{ Temperature $\left({ }^{\circ} \mathrm{C}\right)$} & \multirow{2}{*}{\multicolumn{2}{|c|}{$\begin{array}{c}\text { Relative } \\
\text { Humidity } \\
(\%)\end{array}$}} & \multirow{2}{*}{\multicolumn{2}{|c|}{$\operatorname{ET}\left({ }^{\circ} \mathrm{C}\right)$}} & \multirow{2}{*}{\multicolumn{2}{|c|}{ THI $\left({ }^{\circ} \mathrm{C}\right)$}} & \multirow{2}{*}{\multicolumn{2}{|c|}{ RSI (ratio) }} \\
\hline & & \multicolumn{2}{|c|}{ Minimum } & \multicolumn{2}{|c|}{ Maximum } & \multicolumn{2}{|c|}{ Mean } & & & & & & & & \\
\hline & & $\mathbf{M}$ & SD & $\mathbf{M}$ & SD & $\mathbf{M}$ & SD & $\mathbf{M}$ & SD & $\mathbf{M}$ & SD & $\mathbf{M}$ & SD & $\mathbf{M}$ & SD \\
\hline \multirow[t]{4}{*}{$\begin{array}{c}\text { Tropical Savanna } \\
\text { (Sahel) }\end{array}$} & Nguru & 21.2 & 4.4 & 35.3 & 3.6 & 28.2 & 3.5 & 36.5 & 21.1 & 23.1 & 1.5 & 24.2 & 1.5 & 0.17 & 0.05 \\
\hline & Katsina & 19.4 & 4.3 & 33.7 & 3.4 & 26.5 & 3.5 & 38.9 & 23.5 & 22.5 & 0.6 & 23.3 & 0.6 & 0.13 & 0.02 \\
\hline & Sokoto & 22.0 & 3.6 & 35.2 & 3.2 & 28.6 & 3.0 & 42.7 & 23.6 & 24.4 & 0.6 & 25.4 & 0.6 & 0.19 & 0.03 \\
\hline & Maiduguri & 20.1 & 4.6 & 35.3 & 3.6 & 27.7 & 3.6 & 39.9 & 20.7 & 23.5 & 0.6 & 24.4 & 0.6 & 0.16 & 0.02 \\
\hline \multirow[t]{4}{*}{$\begin{array}{l}\text { Tropical Savanna } \\
\text { (Sudan) }\end{array}$} & Potiskum & 19.7 & 4.5 & 34.4 & 3.3 & 27.0 & 3.4 & 39.5 & 23.9 & 22.4 & 1.3 & 23.3 & 1.2 & 0.13 & 0.10 \\
\hline & Yelwa & 21.3 & 3.6 & 34.1 & 3.0 & 27.7 & 2.3 & 60.7 & 19.1 & 24.9 & 0.5 & 25.5 & 0.7 & 0.18 & 0.06 \\
\hline & Bauchi & 19.0 & 3.5 & 32.7 & 2.8 & 25.8 & 2.6 & 46.7 & 23.1 & 22.4 & 0.7 & 23.1 & 0.7 & 0.09 & 0.10 \\
\hline & Yola & 21.7 & 3.2 & 34.7 & 3.1 & 28.2 & 2.4 & 55.2 & 23.5 & 24.9 & 0.9 & 25.7 & 0.9 & 0.21 & 0.05 \\
\hline \multirow[t]{2}{*}{ Montane } & Jos & 16.0 & 2.3 & 27.6 & 2.3 & 21.8 & 1.7 & 50.0 & 25.9 & 19.4 & 0.3 & 19.6 & 0.4 & 0.01 & 0.01 \\
\hline & Bida & 22.8 & 1.8 & 33.7 & 2.8 & 28.3 & 1.9 & 64.4 & 18.1 & 25.5 & 0.8 & 26.1 & 0.6 & 0.21 & 0.06 \\
\hline \multirow{4}{*}{$\begin{array}{l}\text { Tropical Savanna } \\
\text { (Guinea) }\end{array}$} & Ilorin & 21.3 & 1.7 & 32.2 & 2.6 & 26.8 & 1.6 & 74.4 & 11.6 & 24.4 & 0.5 & 24.9 & 0.5 & 0.17 & 0.02 \\
\hline & Lokoja & 22.8 & 2.0 & 33.0 & 2.4 & 27.9 & 1.7 & 73.4 & 8.2 & 25.9 & 0.7 & 26.3 & 0.6 & 0.22 & 0.04 \\
\hline & Makurdi & 22.3 & 2.5 & 33.3 & 2.6 & 27.8 & 1.8 & 69.8 & 14.2 & 25.4 & 0.9 & 25.9 & 0.7 & 0.21 & 0.04 \\
\hline & Ikeja & 23.1 & 1.3 & 30.9 & 1.9 & 27.0 & 1.4 & 82.6 & 5.8 & 25.3 & 0.6 & 26.1 & 0.6 & 0.21 & 0.04 \\
\hline \multirow[t]{3}{*}{$\begin{array}{l}\text { Tropical Wet } \\
\text { and Dry }\end{array}$} & Benin & 23.0 & 0.8 & 31.3 & 2.0 & 27.1 & 1.4 & 83.9 & 5.7 & 25.9 & 0.6 & 26.1 & 0.6 & 0.21 & 0.04 \\
\hline & Calabar & 22.8 & 1.0 & 30.6 & 1.8 & 26.8 & 1.2 & 85.1 & 5.0 & 25.7 & 0.9 & 25.9 & 0.8 & 0.19 & 0.09 \\
\hline & Warri & 23.1 & 0.9 & 31.4 & 1.8 & 27.3 & 1.2 & 83.9 & 4.8 & 26.1 & 0.4 & 26.3 & 0.9 & 0.22 & 0.02 \\
\hline Tropical Wet & Port Harcourt & 22.4 & 1.2 & 31.1 & 1.8 & 26.7 & 1.1 & 83.4 & 5.5 & 25.6 & 0.4 & 24.8 & 2.1 & 0.20 & 0.03 \\
\hline Overall mean & & 21.4 & 3.4 & 32.8 & 3.4 & 27.0 & 2.8 & 62.0 & 24.8 & 24.1 & 0.9 & 24.8 & 1.8 & 0.20 & 0.18 \\
\hline
\end{tabular}

index, and are generally not well suited for regional physiological or thermal analysis.

The generally lower minimum temperature in the savanna region (than in the tropical wet) indicates that the night-time temperature in this region can vary from cold stress to comfortable climate than obtained in the tropical wet regions while the relatively higher maximum temperature suggests day-time discomfort in the tropical savanna. Temperature can also vary as a result of urbanisation, commercialisation and industrialisation.

Most towns and cities in Nigeria are characterised by transport and commercial activities that are capable of increasing the immediate temperature and contribute to the global temperature [45] (Figure 3). The day-time and night-time discrepancy in the savanna and tropical wet is supported by the difference in the relative humidity in these regions. The tropical wet regions are characterised by thick cloud, which can prevent penetration of solar energy and maximise thermal comfort in the tropical wet, especially in day-time. The savanna region exhibits lower relative humidity, and this suggests less cloud cover with the consequent high radiation (heat) in the region. Conversely, re-radiation of heat can be delayed by the thick cloud cover in the tropical wet region than will be delayed in savanna region.

\subsection{Day-Time Thermal Comfort in Nigeria}

Evaluated thermal indices (THI, ETI and RSI) showed temporal and spatial variations. Peak of the heat stress condition occurred at 1500 LST while the early morning time (before 0900 LST) was more conducive. The two years taken to explain the temporal variations (1971 to represent a typical cool year, and 2001 for a typical warm year), and the results of their moving average interpolations are presented as Figure 4. Figure 4 indicates that 


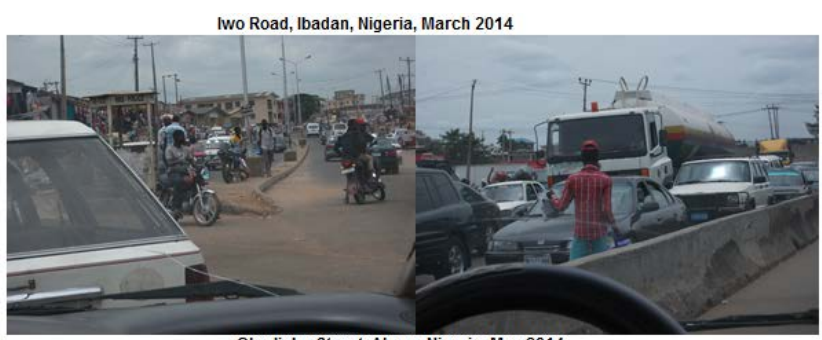

Oke-ljebu Street, Akure, Nigeria, May 2014

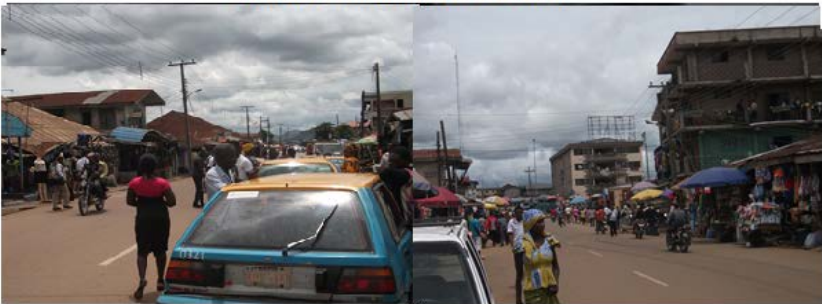

Figure 3. Typical activities that are capable of increasing the thermal condition in the Nigerian urban area. Note the well concretised surfaces and little or no green plants to remove the $\mathrm{CO}_{2}$ from the environment.

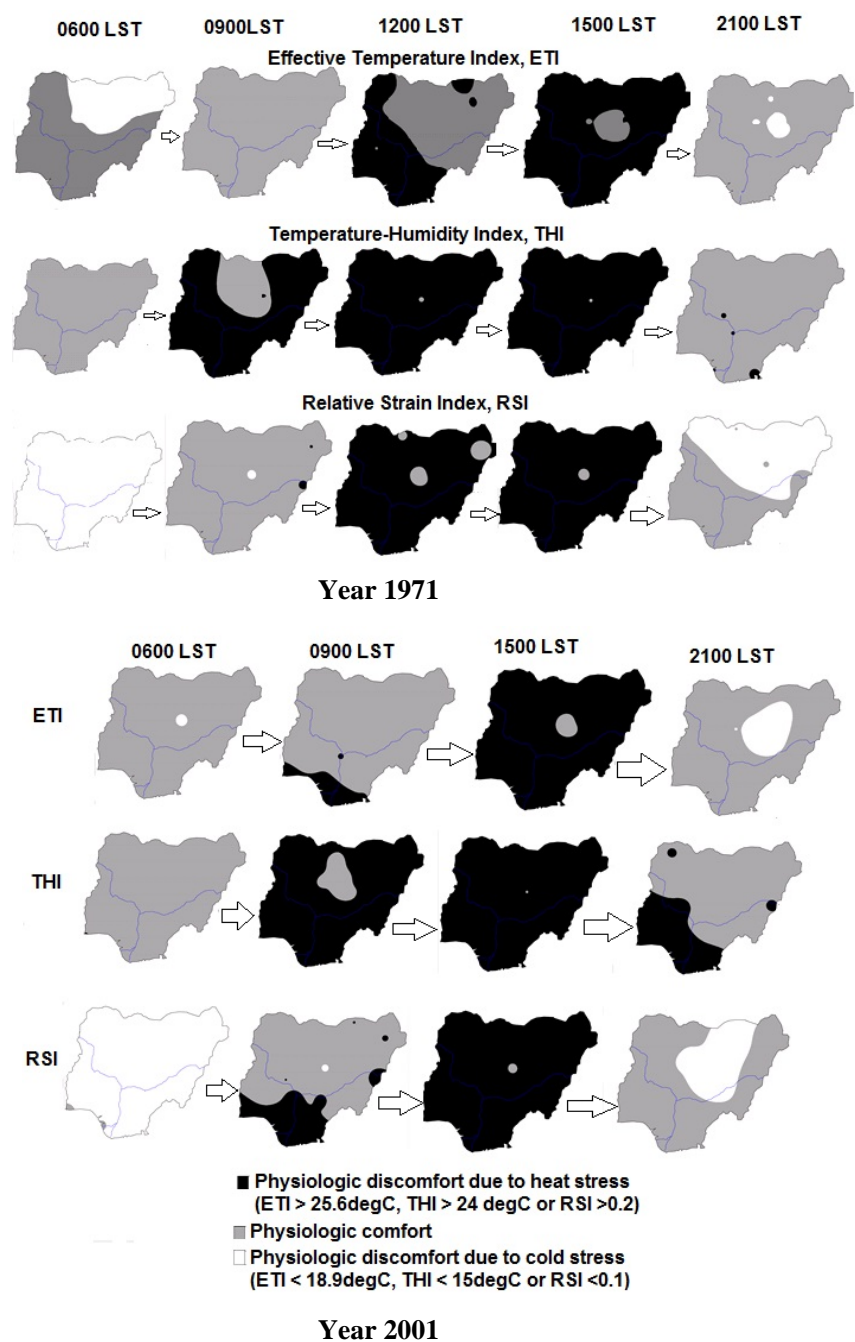

Figure 4. Mean hourly patterns of physiologic comfort in Nigeria for 1971 and 2001 (Note: Data was not available for most stations at 1200 LST in 2001, and was therefore not mapped for the period). 
the interpretations of the day-time thermal comfort for Nigeria (based on the selected stations) using ETI, THI and RSI vary with each of the indices. Thermal comfort in 1971 also exhibited slight difference from that of 2001, especially at 0900 LST and 2100 LST (Figure 4). In general, some of regions (in the northwest) that were mapped to experience cold stress in 1971 were comfortable (some have also exhibited heat stress) in 2001. The tropical wet region also has shown increased level of heat stress around 0900 LST. The ETI map suggests that cold stress condition extended further around the montane region. The results of the comparison indicated a prevalence of cold stress in a typical cool year, and heat stress in a warm year.

On the other hand, the results of the monthly variations of thermal comfort at selected settlements in Nigeria shows that spatial variations occur. The results of ETI and RSI were similar, and therefore only ETI and THI are presented. In both ETI and THI, Lokoja (in the guinea savanna) showed most day-time hours of heat stress (1100 - 1700 LST) while Jos (montane region) exhibited the least number of hours with day-time thermal stress condition. Calabar and Benin (tropical wet) exhibited heat stress in the afternoon (1200 - 1700 LST) in June-October. Heat stress at the tropical wet regions occurred for more hours (1000 - 1700 LST) between November and April. The results of the monthly variations of THI for Lokoja and Jos exhibited different features; heat stress was indicated in Jos (February-April) while ETI and RSI reflected comfortable climate for same period. In other settlements, more hours exhibited heat stress with the THI map than shown with the ETI map (Figure 5).

In general, the results of this study indicated that 1200 - 1500 LST was the most thermally stressful in Nigeria. This is typical of the tropical region where the sun is known to be directly overhead at noon before the heat accumulates and peaks shortly after. Samendra and Ayesha [46] also showed that temperatures and heat conditions usually peak at 1500 hour in Dhaka, Bangladesh, and that more people feel uncomfortable around this hour than other hours of the day. Runnals and Oke [47] also showed that maximum heat condition occurred around this time (afternoon), and argued that the morning and night are usually more comfortable. The monthly and spatial variations indicated that adopting a single index for the Nigerian thermal climate will be fraught with many uncertainties, because the Nigerian climate is influenced by many interacting factors. Studies have shown that factors affecting the Nigerian climate include the movements of the Intercontinental tropical discontinuity, ITD, prevailing air masses, relief, continentality, proximity of river bodies, and anthropogenic factors, including
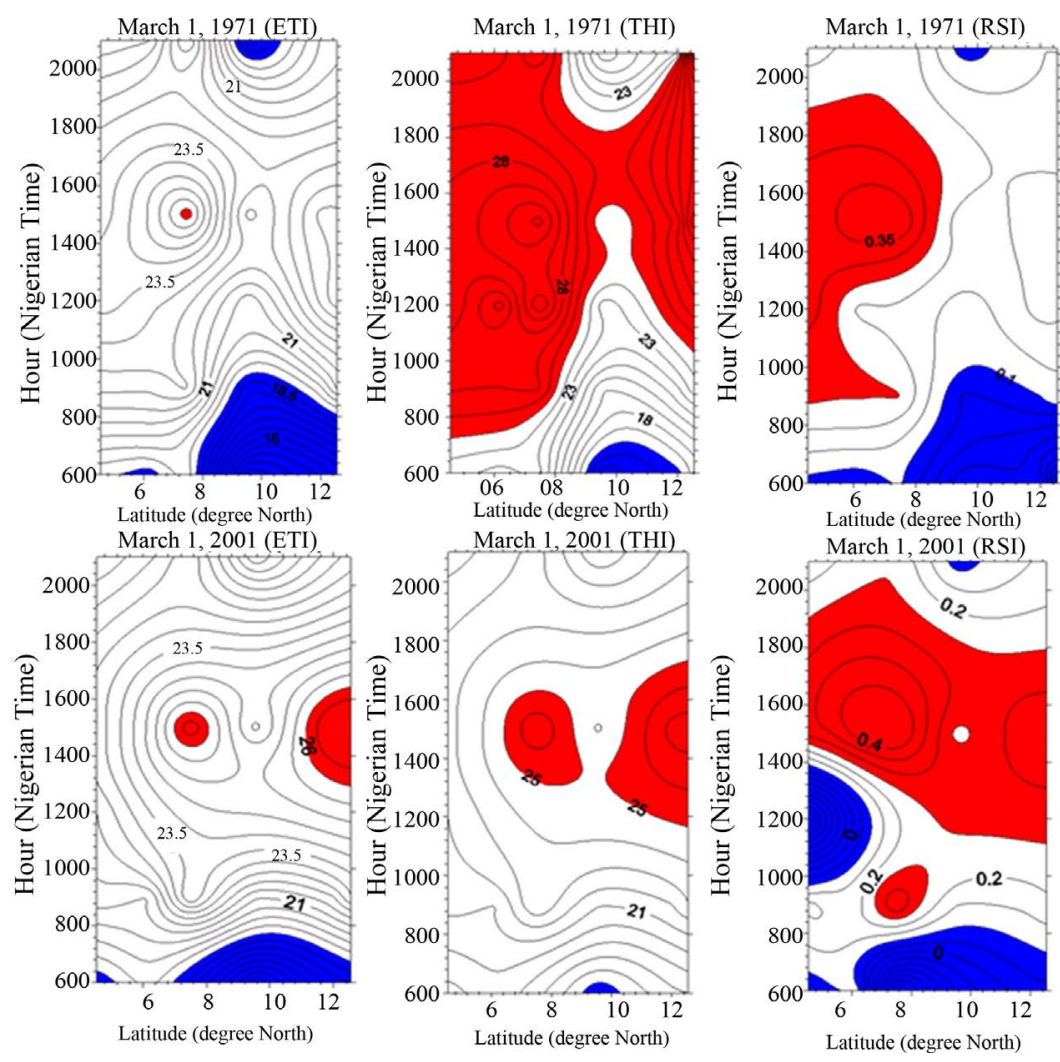

(a) 

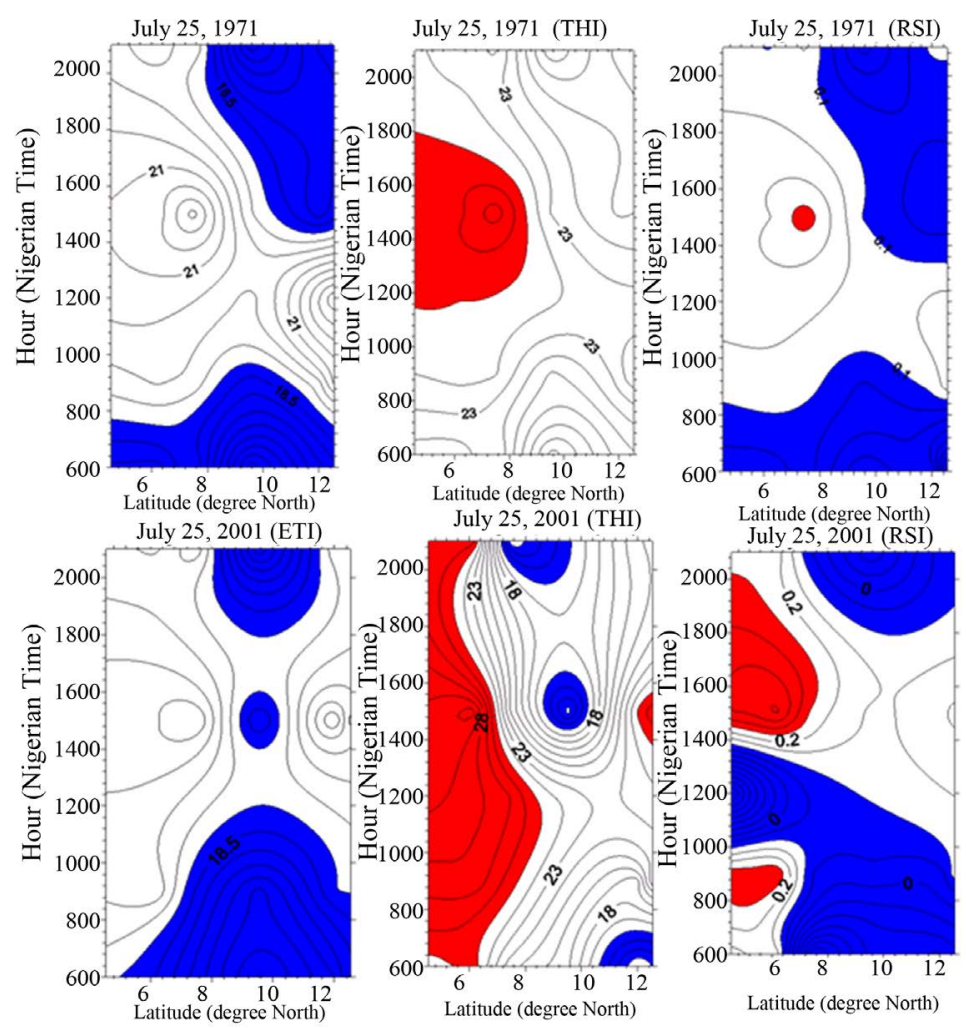

(b)
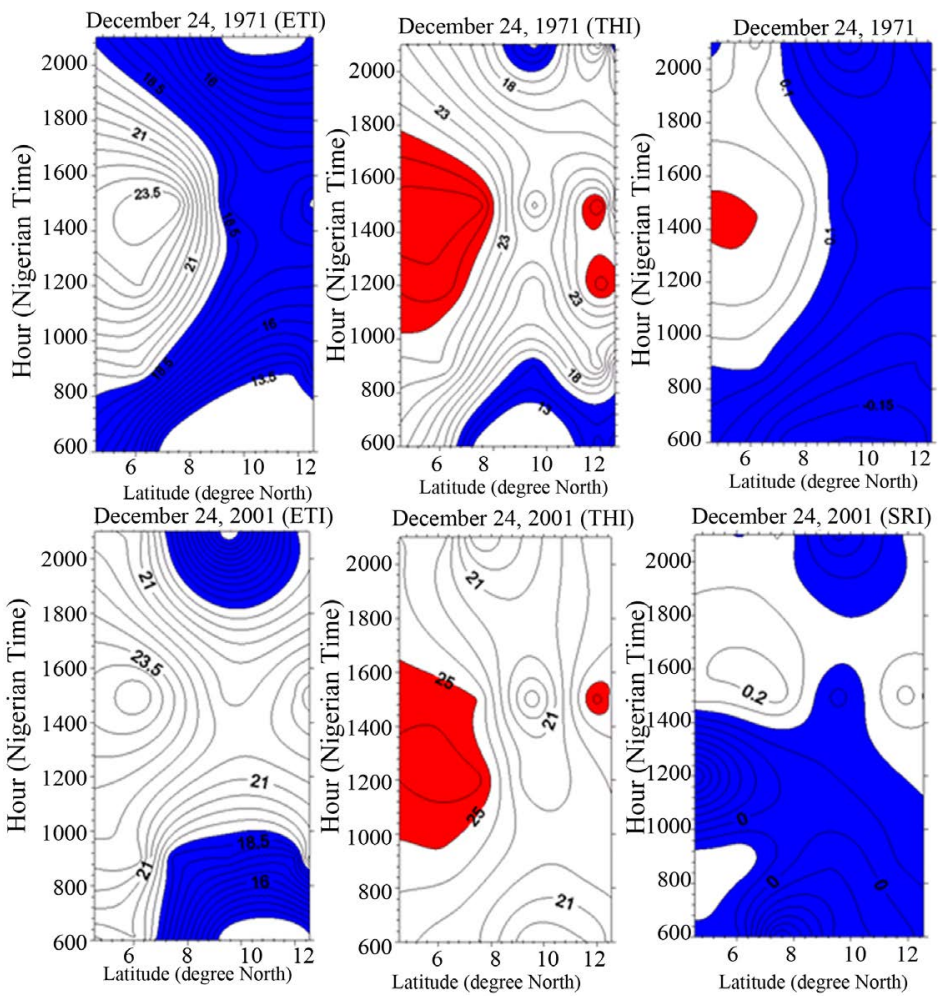

(c)

Figure 5. Representatives of the effective temperature, temperature-humidity and relative strain indices for different time of the year: (a) Dry Season; (b) Wet season; and (c) Harmattan. 
urbanisation, gas flaring activities among others [1] [34] [36] [44]. In general, commerce and industry are growing in many parts of Nigeria, and with them administration and the human population, all of which can also impact the local climate in different regions. Subsequently, since Nigeria is a large country and contains about six climate regions (as noted earlier in the study), and is not as homogenous as in most countries where use of singular thermal index would produce less uncertainty, future study will want to investigate most appropriate for the different thermal model.

\subsection{Responses of Nigerians to Thermal Climate}

Whilst the perceptions of sampled Nigerians varied on the seasonal distributions of heat stress ( $\mathrm{p} \leq 0.05$ for dry season, $\mathrm{p} \geq 0.05$ for Harmattan and rain season), about $50 \%$ from southern (tropical wet) and northern (savanna) regions described the dry season as generally warm and characterized by heat-related morbidity, including headache and heat rash. The Harmattan was described by most respondents $(>70 \%)$ as dusty, windy and linked with dry eyes, dry skin and dry throat while the rainy season is generally cool (and in some cases, cold) and linked with severe cold, headache and cough. About $90 \%$ of the sample populations responded to heat stress condition mainly by alternating their modes of dresses (from thick to thin layered dress in dry season or vice versa in the rainy and Harmattan season. Majority (>64\%) also cover their head and arms as response to the dusty Harmattan or severe cold in both Harmattan and rainy season). While alternating different dressing mode to cope with a prevailing weather is a practice worldwide (Figure 6), people whose income is above the poverty
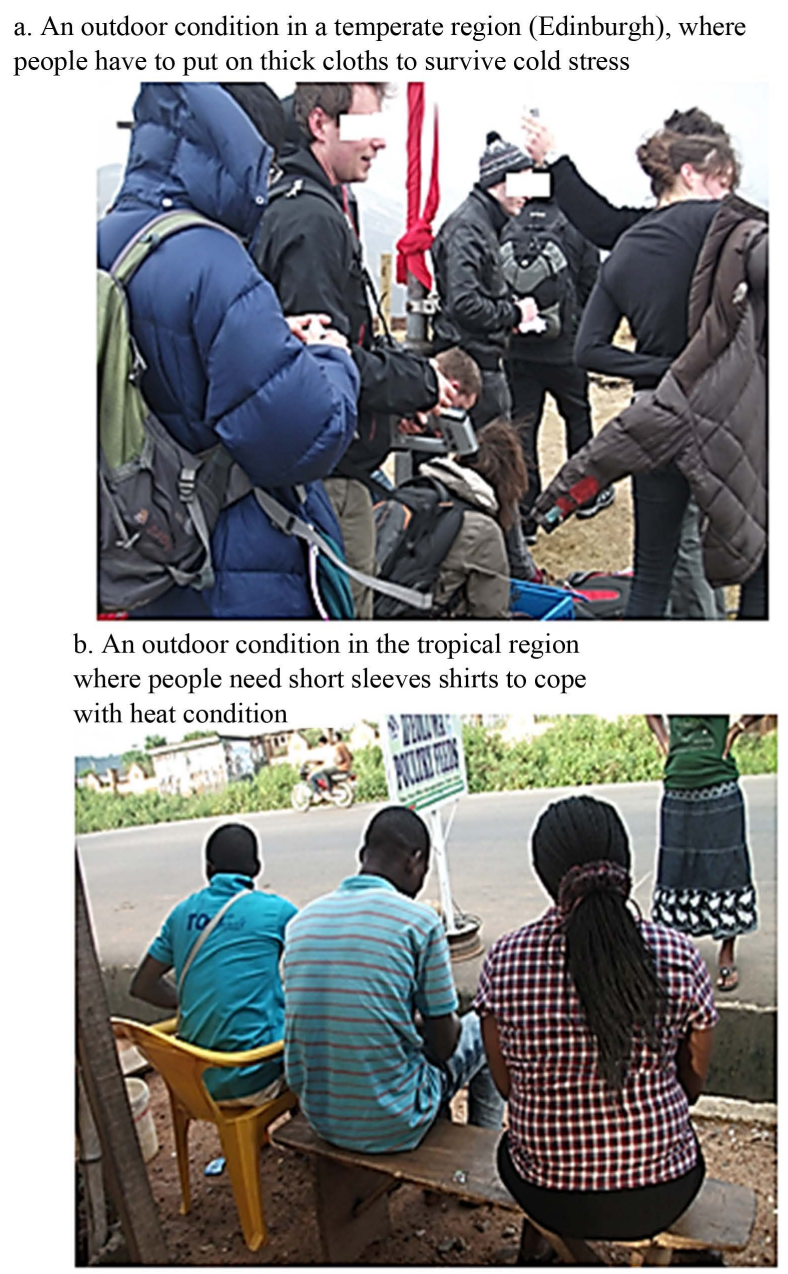

Figure 6. A comparative outdoor dressing between the temperate and tropical climate, showing responses to prevailing climate. (a) is a picture of a set of a field participants in a workshop in Edinburgh, Scotland in April 2013; (b) was taken in Akungba-Akoko, Ondo State, Nigeria in May 2014. 
level (the poor is defined here as those whose concern is primarily on feeding themselves and families) prefer to install air conditioners in their car, house and office (or at least in one of them) in the present study.

Figure 7 shows the preference for meeting the thermal discomfort challenges in the offices and houses. At least $70 \%$ of the entire respondents were however not disturbed about the seasonal variations in the thermal comfort as more than half of the respondents (51\%) largely attributed climate change to "what only god can change" or "what god uses to punish the people where he is angry with them". The responses indicated low awareness to the morbidity and mortality consequences of extreme climate effects. Sawa and Buhari [48] has attributed the outbreak of measles and meningitis in Zaria, Nigeria in the last decade to extreme temperature while many cases of mortality were recorded as a result of heat waves in North America [27] [48]-[50].

However, unlike the other regions which have mapped weather health-response plans [49] [50], Nigeria does not (as at the period of this paper) have a documented plan or any infrastructure to respond to extreme weather events, other than the National Emergency Management Agency, that has often been criticized for its inefficiency [51]. Many reports have indicated that Nigeria, like most developing countries are not prepared for the challenge of extreme climate and climate change, especially because of poor technology and poor resource allocation [30] [32] [52] in a study of the assessment of the millennium development goal scores of Ondo State (in the southwest Nigeria) indicated that most states in Nigeria will poorly perform in the areas of sanitation, water supply and health. Given the results of the peoples' perceptions on thermal climate in Nigeria, it can be generally deduced that poor climate education and sensibility, poor technology (for cost effective, cheap and energy (solar or alternate) saving devices), unequal distribution of financial wealth, poor social welfare schemes (and where they exist, some of the programmes are poorly implemented and severely infested by corrupt or discriminatory practices) are the bane of social infrastructure in Nigeria.

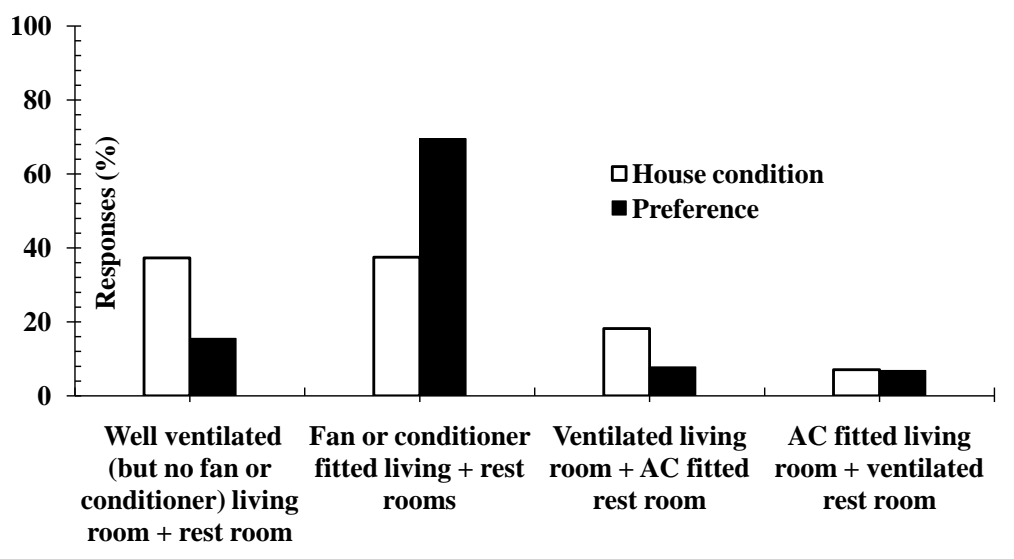

(a)

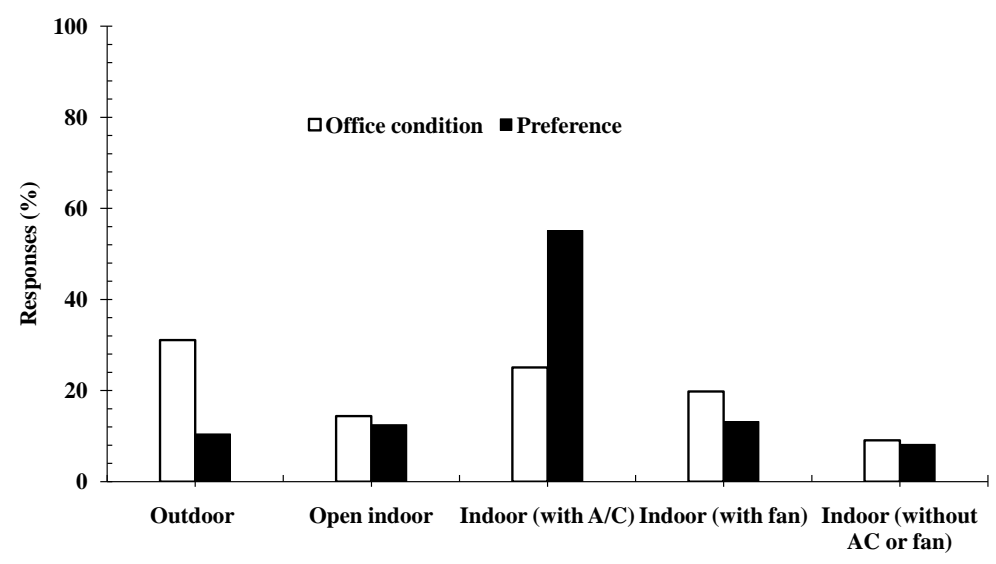

(b)

Figure 7. Available and preferential responses to office and residential plan to cope with thermal stress among 3600 respondents in Nigeria. 


\section{Conclusions and Recommendations}

This study has examined the thermal comfort in Nigeria and the responses to thermal stress. The two hypotheses suggested for the study (that Nigeria is thermally comfortable, and that available coping strategies are sufficient to cope with thermal stress) are rejected. The study showed that thermal stress will increase in Nigeria as urbanization, population and the global temperature increase (although the condition varies seasonally and spatially), and that climate education is largely low among Nigerians. Majority of the respondents lack indigenous approach, and they preferred no precautionary solution to cope with extreme climate other than "prayers". The general perception of the respondents on climate issues was beclouded by religious or ignorant sentiments. The results of this investigation suggest that efficient coping strategies for thermal stress are generally lacking; being limited by poor education, financial capacity and inadequate government commitment to cater for the health effects of extreme climate conditions in poor communities (which incidentally comprises more than half of the Nigerian population [30]. The study concludes that Nigeria, which exemplifies many developing countries, is not yet prepared for the effect of future climate change. The study therefore recommends climate education (with effects of extreme conditions and coping strategies) at all levels of Nigerian education system, improved health schemes for climate-related and improved greening of the urban environment. Indigenous approaches to enhancing adaptation to and coping with thermal stress should also be encouraged.

\section{References}

[1] Adebayo, Y. (1991) Day-Time Effects of Urbanization on Relative Humidity and Vapour Pressure in a Tropical City. Theoretical and Applied Climatology, 43, 17-30. http://dx.doi.org/10.1007/BF00865039

[2] Becker, S. (1998) Beach Comfort Index-A New Approach to Evaluate the Thermal Conditions of Beach Holiday Resorts Using a South African Example. GeoJournal, 44, 297-307. http://dx.doi.org/10.1023/A:1006871805262

[3] Ajibola, K. (2001) Design for Comfort in Nigeria—A Bioclimatic Approach. Renewable Energy, 23, 57-76. http://dx.doi.org/10.1016/S0960-1481(00)00113-0

[4] Ahmed, K.S. (2003) Comfort in Urban Spaces: Defining the Boundaries of Outdoor Thermal Comfort for the Tropical Urban Environments. Energy and Buildings, 35, 103-110. http://dx.doi.org/10.1016/S0378-7788(02)00085-3

[5] Alessandro, A. and de Garín, A. (2003) A Study on Predictability of Human Physiological Strain in Buenos Aires City. Meteorological Applications, 10, 263-271. http://dx.doi.org/10.1017/S1350482703003062

[6] Chappells, H. and Shove, E. (2004) Comfort: A Review of Philosophies and Paradigms. Unpublished Essay. http://www.lancs.ac.uk/fass/projects/futcom/fc litfinal1.pdf

[7] Alcamo, J., Moreno, J.M., Nováky, B., Bindi, M., Corobov, R., Devoy, R.J.N., Giannakopoulos, C., Martin, E., Olesen, J.E. and Shvidenko, A. (2007) Europe. Climate Change 2007: Impacts, Adaptation and Vulnerability. In: Parry, M.L., Canziani, O.F., Palutikof, J.P., van der Linden, P.J. and Hanson, C.E., Eds., Contribution of Working Group II to the Fourth Assessment Report of the Intergovernmental Panel on Climate Change, Cambridge University Press, Cambridge, 541-580.

[8] Boko, M., Niang, I., Nyong, A., Vogel, C., Githeko, A., Medany, M., Osman-Elasha, B., Tabo, R. and Yanda, P. (2007) Africa: Climate Change 2007: Impacts, Adaptation and Vulnerability. Contribution of Working Group II. In: Canziani, O.F., Parry, M.L., Palutikof, J.P., van der Linden, P.J. and Hanson, C.E., Eds., Fourth Assessment Report of the Intergovernmental Panel on Climate Change, Cambridge University Press, Cambridge, 433-467.

[9] Analitis, A., Katsouyanni, K., Biggeri, A., Baccini, M., Forsberg, B., Bisanti, L., Kirhmayer, U., Ballester, F., Cadum, E., Goodman, P.G., Hojs, A., Sunyer, J., Tiittanen, P. and Michelozzi, P. (2008) Effects of Cold Weather on Mortality: Results from 15 European Cities within the PHEWE Project. American Journal of Epidemiology, 168, 1397-1408. http://dx.doi.org/10.1093/aje/kwn266

[10] Lee, D.H.K. (1953) Physiological Climatology as a Field of Study. Annals of the Association of American Geographers, 43, 127-137. http://dx.doi.org/10.1080/00045605309352108

[11] Terjung, W. (1967) The Geographical Application of Some Selected Physio-Climatic Indices to Africa. International Journal of Biometeorology, 11, 5-19. http://dx.doi.org/10.1007/BF01424270

[12] Davis, R.E., Knappenberger, P.C., Michaels, P.J. and Novicoff, W.M. (2004) Seasonality of Climate-Human Mortality Relationships in US Cities and Impacts of Climate Change. Climate Research, 26, 61-76. http://dx.doi.org/10.3354/cr026061

[13] Busch, J.F. (1992) A Tale of Two Populations: Thermal Comfort in Air-Conditioned and Naturally Ventilated Offices in Thailand. Energy and Buildings, 18, 235-249. http://dx.doi.org/10.1016/0378-7788(92)90016-A

[14] Githeko, A. and Woodward, A. (2003) International Consensus on the Science of Climate and Health: The IPCC Third 
Assessment Report. Climate Change and Human Health: Risks and Responses, World Health Organisation, Geneva, 43-60.

[15] Emmanuel, R. (2005) Thermal Comfort Implications of Urbanization in a Warm-Humid City: The Colombo Metropolitan Region (CMR), Sri Lanka. Building and Environment, 40, 1591-1601. http://dx.doi.org/10.1016/j.buildenv.2004.12.004

[16] Bypass, P. (2009) Climate Change and Population Health in Africa: Where Are the Scientists? Global Health Action, 2, 1-4. http://dx.doi.org/10.3402/gha.v2i0.2065

[17] De Freitas, C. and Symon, L. (1987) A Bioclimatic Index of Human Survival Times in the Antarctic. Polar Record, 23, 651-659. http://dx.doi.org/10.1017/S0032247400008354

[18] Ferreira, B., Zanobetti, A. and Schwartz, J. (2001) The Time Course of Weather-Related Deaths. Epidemiology, 12, 662-667. http://dx.doi.org/10.1097/00001648-200111000-00014

[19] De Dear, R.J. and Brager, G.S. (2002) Thermal Comfort in Naturally Ventilated Buildings: Revisions to ASHRAE Standard 55. Energy and Buildings, 34, 549-561. http://dx.doi.org/10.1016/S0378-7788(02)00005-1

[20] De Freitas, C. (2003) Tourism Climatology: Evaluating Environmental Information for Decision Making and Business Planning in the Recreation and Tourism Sector. International Journal of Biometeorology, 48, 45-54. http://dx.doi.org/10.1007/s00484-003-0177-z

[21] Fritch, P., Alexander, L.V., Della-Marta, P., Gleason, B., Haylock, M., Klein Tank, A.M.G. and Peterson, T. (2002) Observed Coherent Changes in Climatic Extremes during the Second Half of the Twentieth Century. Climate Research, 19, 193-212. http://dx.doi.org/10.3354/cr019193

[22] Piccarreta, M., Lazzari, M. and Pasini, A. (2014) Trends in Daily Temperature Extremes over the Basilicata Region (Southern Italy) from 1951 to 2010 in a Mediterranean Climatic Context. International Journal of Climatology, in Press. http://dx.doi.org/10.1002/joc.4101

[23] Kalkstein, L. and Valimont, K. (1986) An Evaluation of Summer Discomfort in the United States Using a Relative Climatological Index. Bulletin of the American Meteorological Society, 67, 842-848. http://dx.doi.org/10.1175/1520-0477(1986)067<0842:AEOSDI>2.0.CO;2

[24] Kalkstein, L.S. (1991) A New Approach to Evaluate the Impact of Climate on Human Mortality. Environmental Health Perspectives, 96, 145-150. http://dx.doi.org/10.1289/ehp.9196145

[25] Kalkstein, L. and Smoyer, K. (1993) The Impact of Climate Change on Human Health: Some International Implications. Experientia, 49, 969-979. http://dx.doi.org/10.1007/BF02125644

[26] Kalkstein, L.S. and Greene, J.S. (1997) An Evaluation of Climate/Mortality Relationships in Large US Cities and the Possible Impacts of a Climate Change. Environmental Health Perspectives, 105, 84-93. http://dx.doi.org/10.1289/ehp.9710584

[27] Smoyer-Tomic, K.E. and Rainham, D. (2001) Beating the Heat: Development and Evaluation of a Canadian Hot Weather Health-Response Plan. Environmental Health Perspectives, 109, 1241-1248. http://dx.doi.org/10.1289/ehp.011091241

[28] Sheridan, S.C. and Kalkstein, L.S. (2004) Progress in Heat Watch-Warning System Technology. Bulletin of the American Meteorological Society, 85, 1931-1941. http://dx.doi.org/10.1175/BAMS-85-12-1931

[29] Kalkstein, A.J. and Sheridan, S.C. (2007) The Social Impacts of the Heat-Health Watch/Warning System in Phoenix, Arizona: Assessing the Perceived Risk and Response of the Public. International Journal of Biometeorology, 52, 43-55. http://dx.doi.org/10.1007/s00484-006-0073-4

[30] United Nations Population Fund, UNFPA (2007) The State of World Population 2007: Unleashing the Potential of Urban Growth. UNFPA, New York, 32 p.

[31] United Nations Environment Programme, UNEP (2002) Global Environment. Nairobi.

[32] World Health Organisation, WHO (2011) Regional Consultation on Health of the Urban. Proceedings of the 2010 Regional Consultation of Mubai, India, Regional Office for South East Asia, UNFPA, 82 p.

[33] Ayoade, J. (1978) Spatial and Seasonal Patterns of Physiologic Comfort in Nigeria. Theoretical and Applied Climatology, 26, 319-337.

[34] Olaniran, O. (1982) The Physiological Climate of Ilorin, Nigeria. Theoretical and Applied Climatology, 31, $287-299$.

[35] Kyle, W. (1994) The Human Bioclimate of Hong Kong. In: Brazdil, R. and Kolar, M., Eds., Contemporary Climatology, Proceedings of COC/IGU Meeting, 15-20 August 1994, Masaryk University, Brno, 345-350.

[36] Iloeje, N.P. (2001) A New Geography of Nigeria. New Revised Edition, Longman Nig. Ltd., Lagos, 200 p.

[37] Aregheore, E.M. (2009) Country Pasture/Forage Resources Profiles: Nigeria. Food and Agriculture Organisation of the United Nations, Italy, $42 \mathrm{p}$. 
[38] Eludoyin, O.M. and Adelekan, I.O. (2013) The Physiologic Climate of Nigeria. International Journal of Biometeorology, 57, 241-264. http://dx.doi.org/10.1007/s00484-012-0549-3

[39] Eludoyin, O.M., Adelekan, I.O., Webster, R. and Eludoyin, A.O. (2014) Air Temperature, Relative Humidity, Climate Regionalization and Thermal Comfort of Nigeria. International Journal of Climatology, 34, 2000-2018. http://dx.doi.org/10.1002/joc.3817

[40] United Nations Statistics Division, UNSD (2013) World Statistics Pocketbook, Country Profile. http://www.un.org/CountryProfile.aspx?crName=Nigeria

[41] Le Treut, H., Somerville, R., Cubasch, U., Ding, Y., Mauritzen, C., Mokssit, A., Peterson, T., Prather, M., Qin, D., Manning, M., Chen, Z., Marquis, M., Averyt, K.B. and Tignor, M. (2007) Historical Overview of Climate Change, Earth 1 (October), Cambridge University Press, Cambridge, 93-127.

[42] Crocombe, R. and Meleisea, M. (1989) Higher Education in the Pacific Islands: Spheres of Influence, Trends and Developments. International Journal of Educational Development, 9, 163-173. http://dx.doi.org/10.1016/0738-0593(89)90044-8

[43] Ogunsote, O.O. and Prucnal-Ogunsote, B. (2002) Defining Climatic Zones for Architectural Design in Nigeria: A Systematic Delineation. Journal of Environmental Technology, 1, 1-14.

[44] Ayoade, J. (1983) Introduction to Climatology for the Tropics. Wiley, Hoboken, 258 p.

[45] Akinbode, O.M., Eludoyin, A.O. and Fashae, O.A. (2008) Temperature and Relative Humidity Distributions in a Medium-Size Administrative Town in Southwest Nigeria. Journal of Environmental Management, 87, 95-105. http://dx.doi.org/10.1016/j.jenvman.2007.01.018

[46] Samendra, K. and Ayesha, K. (1994) The Variability and Probability Extremes of Some Climatic Elements over Dhaka. Reports, The Technical Conference on Tropical Urban Climates, Dhaka, 28 March-2April 1993, 95-115.

[47] Runnals, K.E. and Oke, T.R. (2000) Dynamics and Control of the Near-Surface Heat Island of Vancouver, British Columbia. Physical Geography, 21, 283-304.

[48] Sawa, B. and Buhari, B. (2011) Temperature Variability and Outbreak of Meningitis and Measles in Zaria, Northern Nigeria. Research Journal of Applied Sciences, Engineering and Technology, 3, 399-402.

[49] Kalkstein, L.S., Jamason, P.F., Greene, J.S., Libby, J. and Robinson, L. (1996) The Philadelphia Hot Weather-Health Watch/Warning System: Development and Application, Summer 1995. Bulletin of the American Meteorological Society, 77, 1519-1528. http://dx.doi.org/10.1175/1520-0477(1996)077<1519:TPHWHW>2.0.CO;2

[50] Smoyer, K. (1998) A Comparative Analysis of Heat Waves and Associated Mortality in St. Louis, Missouri-1980 and 1995. International Journal of Biometeorology, 42, 44-50. http://dx.doi.org/10.1007/s004840050082

[51] Omodanisi, E.S., Eludoyin, A.O. and Salami, A.T. (2014) A Multi-Perspective View of the Effects of a Pipeline Explosion in Nigeria. International Journal of Disaster Risk Reduction, 7, 68-77.

[52] Allen, A.A. (2013) Population Dynamics and Infrastructure: Meeting the Millennium Development Goals in Ondo State, Nigeria. African Population Studies, 27, 229-237. http://dx.doi.org/10.11564/27-2-443 
Scientific Research Publishing (SCIRP) is one of the largest Open Access journal publishers. It is currently publishing more than 200 open access, online, peer-reviewed journals covering a wide range of academic disciplines. SCIRP serves the worldwide academic communities and contributes to the progress and application of science with its publication.

Other selected journals from SCIRP are listed as below. Submit your manuscript to us via either submit@scirp.org or Online Submission Portal.
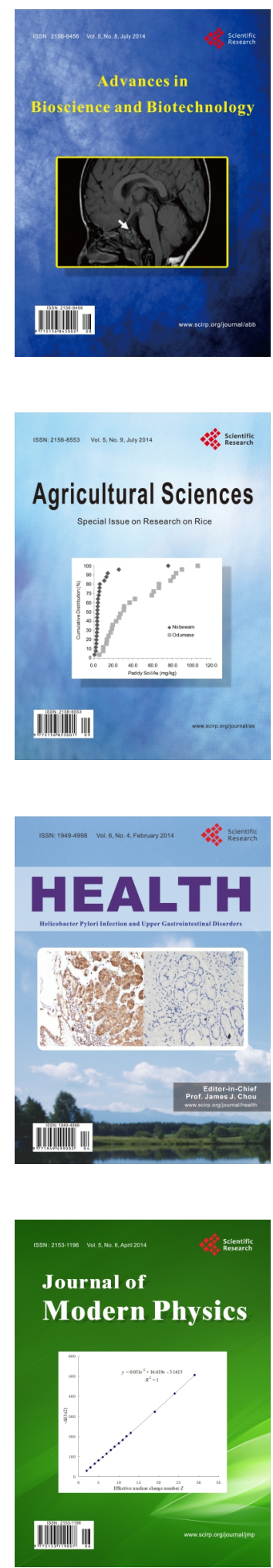
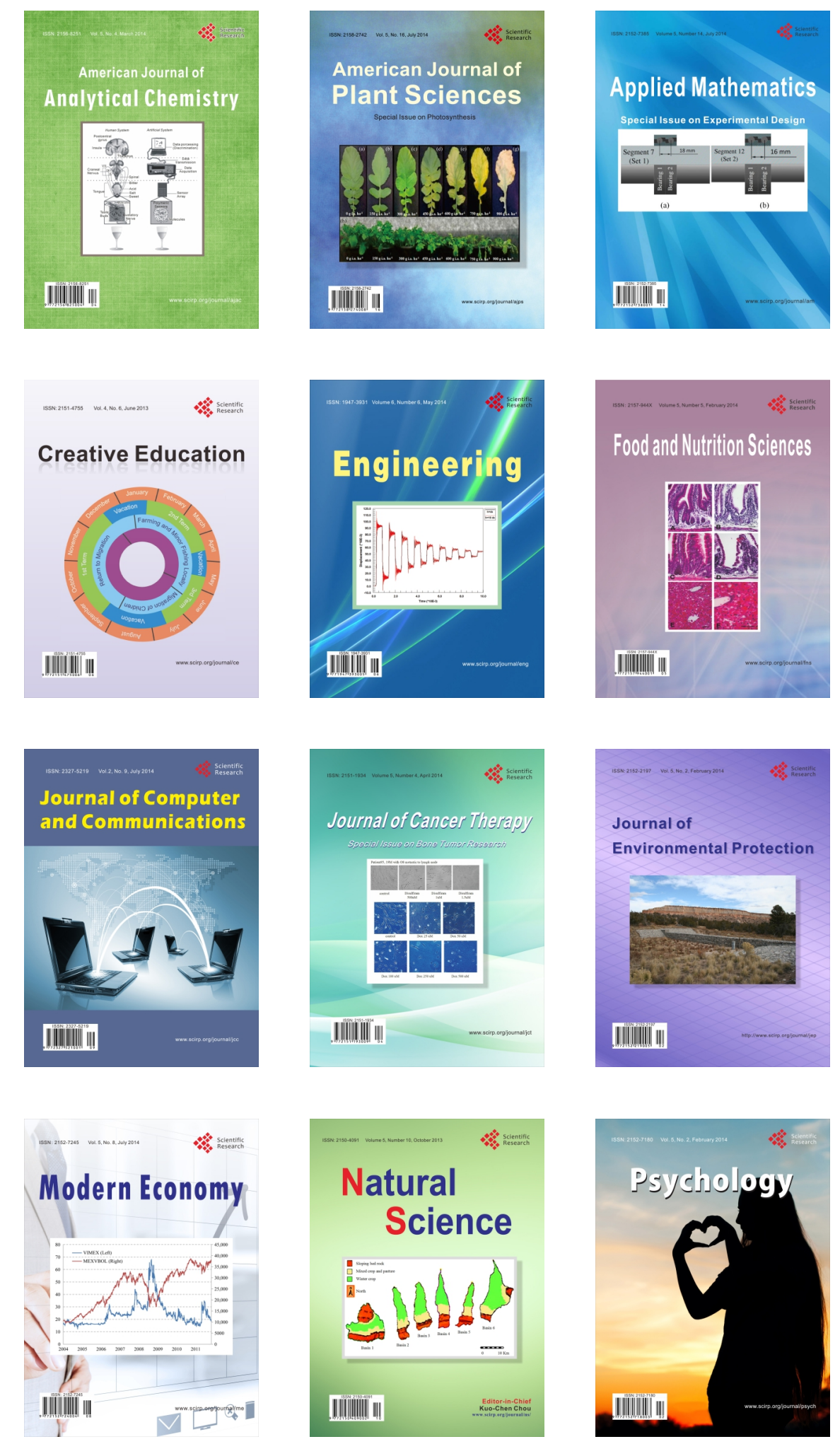